\title{
PROTECTION OF THE LABOR RIGHTS OF CREATIVE WORKERS ACCORDING TO THE LEGISLATION OF FOREIGN COUNTRIES
}

\section{Voloshina S. M.}

\section{INTRODUCTION}

The development of high technologies, the globalization of the economy and economic relations, the emergence of new forms of production, the improvement of existing means of production and the desire to improve production and production processes in the country these are the characteristics that characterize countries with high levels of economy, technological and innovative progress. And usually this development is associated with the creation of a new intellectual product, the development of new technologies, which is carried out using the intellectual resources of employees, using their creative work and creative abilities. For this reason, in highly developed foreign countries, not only are they reasonably well-suited to recruiting staff to work at an enterprise, institution or organization, but also attempting to take appropriate and timely protection for employees engaged in creative activities, to prevent violations of their rights and legal rights. interests, and in the case of infringements with the least cost to restore them.

It should be noted that in foreign countries, unlike in Ukraine, creative work is considered to be one of the highest paid, and workers employed in this field are in high demand for work in enterprises. The importance of creative work and creative activity is guaranteed by a number of legal acts in this field, legal, material and procedural guarantees for the proper realization and protection of the violated rights of creative workers. Countries with a high awareness of the need for creative work and intellectual activity at the legislative level establish an effective and effective mechanism for the protection of intellectual property rights, and workers who perform creative tasks are given a number of benefits and benefits, and additional safeguards for the protection of intellectual property are provided.

Analyzing the legislation of Ukraine in the field of intellectual activity, we have already emphasized the absence of a clear mechanism for the protection of the rights of creative workers in the performance of 
their work function, noted the lack of proper organizational, material, legal mechanism to ensure the protection of the rights of creative workers, inconsistency of legislation in this field.

\section{The rights of creative workers}

The rights of creative workers should be explored in the context of the protection of intellectual property rights and copyright, as these categories are quite close and closely related. In addition, it should be noted that research on copyright in foreign countries should emphasize the various approaches to the regulatory regulation of the rights of creative workers for the Anglo-Saxon and continental system of law. Under the Anglo-Saxon system, both natural and legal persons may be the author of copyrights generally reduced to property rights which can be freely transferred to other persons.

The Anglo-American tradition emphasizes the principle of ownership or the economic aspect of copyright that can be protected and transferred, for which tax can be deducted. A variety of works can be granted copyright privileges. According to the continental (European) system (France, Germany, Russia, Ukraine and other countries), only an individual can be the author of a clearly divided personal and property right. Personal rights always belong only to the author, and property may be represented by other persons, but with a restriction. The European tradition puts forward the idea of moral rights (droit d'auteur) as the highest priority, allowing authors to protect the integrity of their work and to claim authorship ${ }^{1}$. Thus, the mechanism of protection of workers' labor rights should be considered taking into account the peculiarities that are inherent to each state, based on its historical development, regulatory and consolidation of the rights and freedoms of the author, the degree of protection of property and non-property rights of the author or creator of the object intellectual property rights.

Let us examine in detail the degree of legal protection of intellectual property objects in various foreign countries. Investigating and analyzing foreign experience of protecting the creative rights of workers in Ukraine and in the laws of other countries of the world, it is worth emphasizing the common feature of Ukrainian and world law, which is that the property rights and created object of intellectual property rights belong to the

1 Охорона авторського права в Україні. URL: http://osvita.ua/vnz/reports/ culture/11257. 
author. However, the degree of ownership of such rights in different states is different, which is conditioned by the distribution of intellectual property (creative) results between employees who create intellectual property objects and employers. In turn, as noted by D.R. Gotsin, the French Intellectual Property Code does not even refer to the employer as a person who has any copyright in a work performed in connection with the performance of an employment contract (other than hereditary rights to computer programs), but the alienation of the rights created by only possible under a separate civil contract. At the same time, US law defines exclusively the employer as the owner of copyright for official works ${ }^{2}$.

Thus, the laws of foreign states provide for a different distribution of the rights to the results of intellectual activity in respect of employees who have created a relevant intellectual object in the course of performing their work function. Thus, the laws of individual states (France) protect the rights of the worker, securing for him the exclusive rights to use the object created by him, giving him the appropriate property rights in relation to such object, and at that time, which in other countries is preferred The employer is entitled to copyright and works created in the course of the employee's creative activity.

In addition, we emphasize that in different legal systems of the world the rights to intellectual property are defined differently. In the United Kingdom, Spain, Portugal, France, the Federal Republic of Germany, Japan, the United States and some other countries, intellectual property results are recognized as property rights. In Austria, Belgium, Greece, the Netherlands, the Scandinavian countries, Switzerland, Egypt and some other countries, the same result is recognized as objects of exclusive right of use $^{3}$. Such distribution, of course, involves the use of various legal means and means of protection of intellectual property rights. We, however, agree with the view supported by our legislator that the created rights should be attributed to the objects of property rights, which greatly enhances their protection and protection.

Analyzing the norms of the current legislation in the Civil Code of Ukraine and the Code of Labor Laws for the work of creative workers, we note that there is almost no legal definition of their rights and obligations. The practice of foreign countries more closely approaches the

${ }^{2}$ Гоцин Д.Р. Авторське право на студентські роботи // Молодий вчений. 2015. № 12 (27). Ч. 3. С. 79-83.

${ }^{3}$ Право інтелектуальної власності: підручник для студентів вищих навч. закладів / [за ред. О.А. Підопригори, О.Д. Святоцького]. К.: Ін Юре, 2002. 624 с. 
problem of normative-legal fixing of the rights of creative workers in the relevant regulatory legal acts on their regulatory regulation.

The Labor Code of Ukraine does not clearly define and provide for the peculiarities of regulatory regulation of creative workers, which, in turn, causes a number of problematic issues in the regulatory regulation of their rights and duties, as well as the protection of their rights.

The Labor Code does not clearly define and provide for the specific legal regulation of the work of creative workers, which, in turn, raises a number of problematic issues in the legal regulation of their rights and duties, as well as their protection. The current legislation of Ukraine does not provide clear criteria for determining the peculiarities of regulating the work of creative workers, such as for the work of young people, minors, women, etc.

Therefore, the Labor Code should clearly stipulate the peculiarities of regulating the work of creative workers, which, in our opinion, may consist of the following: 1) contract, civil contract, copyright contract, contract agreement, etc; 2) working conditions of the creative worker, which consist not only in the proper organizational and logistical support of the creative workers by the employer, but also protection against those factors that do not depend on the employer or employee (for example, protection of the creative worker from downtime; 3) normalization of labor. It is worth noting that the normalization of the work of the creative worker is quite difficult to understand the concept that follows from the specifics of creative activity; 4) remuneration. A characteristic feature of creative work in foreign countries is that intellectual work in highly developed countries is paid higher than in other countries. In particular, he cites some statistics in his scientific research, which states that in foreign countries, as a rule, mental work is paid higher than physical labor.

According to research, the wages of intellectual workers are on average higher than the wages of workers: in Germany - by 20\%; Italy and Denmark - by 22\%; in Luxembourg - by $44 \%$; France and Belgium by $61 \%$. The average wage of American engineers is almost twice as high as the average wage of workers ${ }^{4}$. An important guarantee for the protection of the right of creative workers is the timely receipt of wages and appropriate compensation for the creation of an intellectual property object.

${ }^{4}$ Баранов В.В. Світовий досвід побудови ефективної системи оплати праці на підприємстві // Наукові праці Кіровоградського націон. техн. Ун-ту. Економічні науки. 2011. Вип. 2. Ч. І. С. 139-145. 
Another object that needs regulation is the right to rest, which is also not clearly regulated in relation to creative workers. In the scientific literature, the term "sabbatical", which is considered as a separate type of holidays. provided for by applicable law. As part of our research, we propose to consider creative leave in relation to creative workers.

A characteristic feature of the legislation in the field of intellectual activity of foreign countries is that highly developed countries approach the problem of protection of intellectual property fairly carefully, defining a number of offenses in this area and establishing sufficiently significant responsibility for infringement of intellectual property rights. In particular, the legislation of France, unlike the national legislature, establishes a rather broad list of offenses in the field of intellectual property.

Thus, the French Trademark Law establishes as the main types of infringements: counterfeiting - the reproduction of another's mark, registered for identical or similar goods and services (for the occurrence of both civil and criminal liability, it is not necessary to prove the guilt of the counterfactor, the very fact of its implementation); misguided imitation - the approximate reproduction of another's sign capable of causing the risk of confusion between the original and the imitated sign (responsibility arises in the presence of guilt in the form of intent); the use of trademarks without the consent of interested persons and the use of imitated trademarks (responsibility comes from the presence of a commercial purpose of the offender, the purpose of profit); erroneous marking - the use by an unauthorized person for the commercial purposes of a genuine, original mark of another person to mark their goods and services; substitution of goods or services - the supply of goods or the offering of services other than those ordered under the registered trademark; storage, sale and delivery - unlawful storage of counterfeit, by deception of marked and imitated signs, as well as sale, putting into circulation, delivery or offer for delivery of goods or services marked with the corresponding signs ${ }^{5}$.

The current legislation of Ukraine provides for significantly fewer offenses in the field of intellectual activity and little responsibility for violations of the rights of creative workers. For example, the Code of Administrative Offenses Code provides for liability solely for such types of offenses as infringement of intellectual property rights (Article 512),

${ }^{5}$ Мироненко Н.М. Захист прав на торговельні марки: українська практика та європейський досвід // Право України. 2011. № 3. С. 30-39. 
unfair competition, which consists in the illegal copying of the form, packaging, external design, and so on. imitation, copying, direct reproduction of another entrepreneur's goods, unauthorized use of his name (Article 1643), demonstration and distribution of films without a state license for distribution and demonstration violation of the conditions for distribution and display of films stipulated by the state certificate for the right of distribution and display of films (Article 1647), illegal distribution of copies of audiovisual works, phonograms, videograms, computer programs, databases (Art. 1649), violation of the law governing the production, export, import of disks for laser reading systems, export, import of equipment or raw materials for their production (Art. 16413) ${ }^{6}$. The sanctions of these articles predominantly provide for the imposition of a fine on offenders and, in exceptional cases, the confiscation of certain items.

Counterfeiting can be considered as part of another offense - piracy, the essence of which is the reproduction of a work, phonogram, audiovisual work, computer program, etc. by fraudulent use of the name, trade name or trademark of the legal publisher, manufacturer, licensee, etc. In these cases, as a rule, there is also an offense related to the counterfeit use of the company name ${ }^{7}$. Exploring counterfeiting as a type of infringement of copyright and intellectual property rights, it should be noted that some aspects of the understanding of counterfeit goods are covered in the Customs Code of Ukraine and the Law of Ukraine "On Copyright and Related Rights". For example, Article 4 of the Customs Code of Ukraine (Article 17, Clause 4) provides for the definition of counterfeit goods, which recognize goods containing intellectual property rights whose import to the customs territory of Ukraine or export from this territory is a violation of intellectual property rights. property protected under the Law. A similar norm is enshrined in Art. 1 of the Law of Ukraine "On Copyright and Related Rights" contains the definition of a counterfeit copy, which is considered a copy of a work, phonogram or video, reproduced, published and (or) distributed in violation of copyright and (or) related rights, including copies protected in Ukraine of works, phonograms and videograms imported into the customs territory

\footnotetext{
${ }^{6}$ Кодекс України про адміністративні правопорушення від 07.12.1984 № 8073-Х // Відомості Верховної Ради УРСР. 1984. № 51. Ст. 1122.

${ }^{7}$ Право інтелектуальної власності: акад. курс: підруч. для студ. вищих навч. закладів / [О.П. Орлюк, Г.О. Андрощук, О.Б. Бутнік-Сіверський та ін.]; за ред. О.П. Орлюк, О.Д. Святоцького. К.: Ін Юре, 2007. 696 с.
} 
of Ukraine without the consent of the author or other subject of copyright and (or) related rights, in particular from countries where these works, phonograms and videograms have never been protected or ceased whether to be protected.

However, it should be noted that more detailed regulation of counterfeiting in the current legislation is not provided, nor are there clear limits of legal liability for this type of offense. Thus, the Customs Code of Ukraine only provides for liability for the importation into the customs territory of Ukraine or export of goods intended for industrial or other business activities outside the territory with violation of the intellectual property rights protected by law (Article 476), which is expressed in the imposition on the offender of the imposition a fine of one thousand nontaxable minimum incomes of citizens with the confiscation of goods moving in violation of intellectual property rights.

We believe that the above article does not fully regulate counterfeiting, and therefore the responsibility for this type of offense solely in the Customs Code is insufficient. In view of the above, and having examined the scientific positions of scientists on the definition of offenses in the field of intellectual property, we propose in the current legislation, namely the Code of Ukraine on Administrative Offenses to hold responsible for such types of offenses as counterfeiting. Equally important today are such offenses as misguided imitation, erroneous marking, the responsibility for which must also be defined and enshrined at the legislative level, by amending the current Code of Administrative Offenses and fixing relevant articles for the above types of offenses ${ }^{8}$.

With regard to criminal liability for infringement of copyrights, intellectual property rights, rights of employees engaged in creative activities, it should be noted that the current Criminal Code establishes liability solely for: infringement of copyright and related rights; infringement of the rights to the invention, utility model, industrial design, topography of the integrated circuit, plant variety, rationalization proposal; the illicit manufacture, falsification, use or sale of illegally made or counterfeit control stamps for marking the packaging of copies of audiovisual works and phonograms; unlawful use of a trade mark (mark for goods and services), 9 commercial (trade name), geographical

${ }^{8}$ Вахонєва Т.М. Захист трудових прав творчих працівників за законодавством держав світу // Наука і правоохорона. 2015. № 1. Ч. 2. С. 37-42. 
indication; - unlawful collection in order to use or use commercially confidential information ${ }^{9}$.

Unfortunately, the Ukrainian legislature has not analyzed the experience of foreign countries and international legal norms related to the protection of intellectual property rights and copyright objects and does not provide for criminal liability in the field of intellectual property for certain types of offenses. In addition, analyzing the experience of foreign countries and international communities in the field of protection of intellectual property rights, we can conclude that the liability for certain types of crimes with statutory liability is disproportionate. In particular, we consider it necessary in the Criminal Code of Ukraine to increase responsibility for plagiarism.

\section{The protection of intellectual property rights and the labor rights in foreign countries}

The protection of intellectual property rights in foreign countries is carried out at a rather high level, which, as we have repeatedly emphasized, is due to the special attitude towards creative workers and their creative activity. Proper protection of intellectual property rights, protection and protection of copyright are one way of stimulating scientists to pursue intellectual and creative activities and further scientific research in the relevant area of scientific knowledge. It should be emphasized that the protection of intellectual property and copyright is also actively pursued internationally, usually in specific, specific areas of activity, such as in the field of protection of computer programs, literary works, copyright and related rights, etc. In particular, a number of important international legal acts concerning the protection of the rights of scientists and creators of intellectual property rights have been adopted today. One such act should be referred to as the Agreement on TradeRelated Aspects of Intellectual Property Rights (TRIPS Agreement).

In exploring the rules of this Agreement, O.O. Krupchan stresses the condition of the agreement, according to which the member states of the Agreement may provide in their national law the right of courts to demand from the offender information about third parties involved in the production and distribution of goods and services that violate the ownership of the sign, as well as their distribution channels. Also

${ }^{9}$ Кримінальний кодекс України: Закон України від 05.04.2001 № 2341-III // Відомості Верховної Ради України. 2001. № 25. Ст. 131. 402. 
interesting is the provision of the Agreement on damages to the defendant. According to this provision, a defendant who, at the request of the owner of an intellectual property object, has taken precautionary measures that have unreasonably restricted the defendant in his rights or completely deprived them, and as a result of which he has been inflicted certain damages, has the right to claim compensation for damage caused as a result. such abuse, including attorney's fees ${ }^{10}$. We consider this position to be sufficiently substantiated as it establishes additional safeguards for the protection of the rights of intellectual property creators. That is, the responsibility in this case rests not only on the direct infringer of the creator's rights, but also on persons who are in one way or another involved in the infringement of intellectual property rights. This, in our view, is quite important, since intellectual property rights and copyright are specific objects of protection both by the state and by the courts and law enforcement agencies. The importance of obtaining information on third parties involved in the production and distribution of goods and services that violate the ownership of the sign, as well as their distribution channels is acquired in the process of self-protection of infringed herbs and legitimate interests of intellectual property objects by the sub further used by the courts in the direct examination of cases. This is due to the fact that in the process of self-defense appropriate circumstances of violation of the rights of the creative worker are established, and quite often in the process of investigation it is established not only when the persons who directly committed the violation and those who in one way or another contributed to the implementation of such violation of rights and interests.

Analyzing the experience of foreign countries, it should be emphasized that in some states, only literary works that are given only certain features are subject to the protection of labor rights and intellectual property rights. For example, one of these features is a sign of originality. Investigating this feature A.M. Yevkov notes that the originality of the work is a matter of fact. Originality cannot be judged equally in all kinds of works. It differs depending on whether it is a work of science and technology or a work of art, literature, popular or symphonic music, original or derivative work. There is no need for the author to be free from

10 Крупчан О.О. Міжнародно-правові механізми охорони і захисту авторських прав // Питання розвитку права інтелектуальної власності: збірник наукових праць. 2009. Вип. 8. С. 109-110.. 
outside influences. The ideas used by the author may be as old as the world, but this does not prevent the work from being original, since, as stated earlier, copyright considers intellectual creativity based on preexisting elements. The main thing here is that the work is different from its predecessors, that the wine is not a copy or inheritance of another work ${ }^{11}$.

In particular, such a position expressed in Romanian law in the Law of Ukraine "On Copyright and Related Rights" states that the subject matter of copyright is original works of intellectual creativity in the field of science, regardless of the way of creation, means or practical form of expression and regardless of their value or purpose ${ }^{12}$. We agree with the above position of the scientist, because the originality of the work originates from the creative nature of the work, the development of creative and mental abilities of the creator, etc. Originality is a prerequisite for recognizing a work as being within the meaning of an intellectual property object, characterizing it as a particular intellectual property. However, in addition to originality at the legislative level, there are also other conditions for recognizing a work as an intellectual property. Yes, the Law № 158 of 31.05. In 1961, it was stipulated that the object of legal protection under paragraph 1 of the Danish law was precisely the work in its special, individual design, which was provided to it by the author. Copyright protection is known to have a very limited territorial nature and belongs to the category of exclusive rights. The exclusiveness of copyright lies not only in the personification of any of the rights under consideration, in the identification of this right with its owner, but also in the fact that, unlike ordinary property relations, where a creditor with his rights is opposed by a particular debtor with his obligations any person and society as a whole is opposed by the copyright owner ${ }^{13}$.

Describing the work of creative workers, we note that in foreign countries, much attention is paid to certain conditions for creative work. In particular, it concerns the norms of the work schedule and the work schedule, which follows from the peculiarities of the creative activity. For example, creative workers can only work a couple of hours a day, and in some cases, almost 24 hours a day. In addition, employers often enter

11 Авторське право в міжнародно-правовому аспекті / Уклад. А.М. Євков Х.: 2010. $126 \mathrm{c}$.

${ }^{12}$ Про авторське право і суміжні права: Закон Республіки Румунія від 14.03.1996 № 8 / http://www.wipo.int/wipolex/ru/text.jsp?file_id=129487.

${ }^{13}$ Шибаєва Л.Л. Деякі особливості міжнародно-правової охорони права інтелектуальної власності // Форум права. 2016. № 3. С. 277-282. 
into civil contracts with creative workers. For example, with actors, writers and artists ${ }^{14}$. An important guarantee for the protection of the rights of creative workers, which arises from the peculiarities of their work, is protection against downtime, which is not provided for by the current Labor Code.

The current legislation of Ukraine does not provide a by-law for the protection of creative workers from downtime, and therefore we consider it necessary, as in most countries, to consolidate this norm at the legislative level.

It should be noted that the experience of foreign countries testifies to the widespread application of the system of material support to employees of enterprises, institutions, organizations, increasing the level of their material support. As V.V. Baran, the key elements of material incentives for employees are: use of the tariff system; the use of progressive forms of remuneration; the dissemination of original bonus systems and incentives for innovation; higher pay for mental work; substantial individualization of wages ${ }^{15}$. The work of creative workers is no exception. In addition, they practice such a form of work motivation abroad as a flexible work schedule. This provides employees with an opportunity to work from home, which greatly improves their attitude to work and, consequently, improves their quality. In addition, when working from home, an employee can perform much more work.

In British firms, the promotion of gifts has become widespread. Another effective way of motivating work is to create self-governing groups. The groups independently decide on issues related to work planning, meetings, coordination with other department etc. ${ }^{16}$. We believe that at the legislative level, the ability of creative workers to use flexible working conditions should be enshrined and the opportunity for creative workers to work on creating an intellectual property right at home should be legislated.

Exploring the legal status of creative workers, I. Bogdan gives an example of international norms in this field. Thus, the scientist notes that

${ }^{14}$ Шадрина Т. С. Особенности трудового договора с творческими работниками // Учреждения культуры и искусства: бухгалтерский учет и налогообложение. 2012. № 11. C. 58-69.

${ }^{15}$ Пресняков М. В. Особенности регулирования труда лиц до 18 лет // Трудовое право. 2010. № 6. С. 11-21.

16 Заярна Н.М. Зарубіжний досвід мотивації праці та доцільність його застосування в України // Науковий вісник НЛТУ України. 2011. Вип. 215. С. 368-372. 
the international norm is more universal in the matter of classification of a person into the category of "creative workers" and establishes the guarantees provided by the legislation on labor for all workers, regardless of what legal basis the person performs work, which in its content is creative, determining her status as a creative worker. It is stated that the legal status of the "creative figure" is not defined, and therefore, does not carry the legal burden, and therefore does not determine the rights and/or obligations. The author also stresses that the continuation of discussions about understanding the concept of "creative worker" is also a mistake. A person who refers to himself as a creative worker voluntarily agrees to the status of "free artist", whose activity, according to such a person, is not regulated by labor law, and therefore cannot be protected by labor and legal means ${ }^{17}$.

The importance of protecting the labor rights of creative workers as jurisdictional and non-jurisdictional bodies is of particular importance. An important element of the protection of the labor rights of workers, including those engaged in creative work, is that in foreign countries there are specialized labor courts and the procedural procedure for the protection of labor rights is clearly regulated at the legislative level. In particular, such courts exist in Austria ${ }^{18}$, Great Britain ${ }^{19}$, USA, Germany, etc. It is worth agreeing with the opinion of A.S. Matsko and J.Ya. Kiselyov, who noted that access to labor courts in European countries for workers is wider than in ordinary courts: the dispute procedure is faster and cheaper, there are no formalities observed in civil proceedings, the courts show greater initiative in litigation and litigation. evidence. There are differences in both the burden of proof (which is mostly on the owner) and the methods of proof. According to A.S. Matsko and J.Ya. Kiselev, the creation of labor courts, the active development of labor justice - the logical conclusion of the recognition of the autonomy of labor law. The specific features of labor law dictate the need to form procedural forms and procedural law in general ${ }^{20}$.

${ }^{17}$ Богдан І.А. Умови праці як елемент трудо-правового забезпечення творчості // Юридична Україна. 2013. Вип. № 7 (127). С. 50-56.

${ }^{18}$ Пархомчук С.О. Шляхи впровадження в судову систему України органів патентної юрисдикції // Часопис Київського університету права НАН України. 2012. № 2. С. 228-231.

${ }^{19}$ Орлова В.В. Как работают патентные суды Германии и Великобритании // Патенты и лицензии. 2007. № 5. С. 57-66.

${ }^{20}$ Порівняльне трудове право: навч. посіб. / [Б.С. Беззуб, Л.В. Голяк, О.М. Кісілевич та ін.]. К.: МАУП, 2005. С. 79-114. 
The laws of some highly developed countries provide for the existence of a specialized judicial body to hear cases arising from the use of intellectual property and intellectual property rights. The existence of such specialized courts is conditioned by the need to possess appropriate practical knowledge in the field of intellectual property, the peculiarities of the exercise of such protection, which greatly speeds up the consideration of such cases, and therefore the speedy restoration of the infringed right.

The most specialized specialization of courts in the field of intellectual property is in Germany. Thus, according to a judge of the Federal Supreme Court of Germany, Professor Joachim Borkamm, the Federal Patent Court operates in Munich. denial of patent or trademark registration). Another function of the Patent Court is to hear claims for patent validity. In Germany, after a patent has been granted, it can only be challenged in the Federal Patent Court and, on appeal, in the Federal Supreme Court. In the course of patent infringement proceedings, a judge must recognize the grant of a patent. He may initiate patent infringement proceedings only if, in his estimation, the patent is most likely to be declared invalid. In civil litigation in Germany, claims are also dealt with exclusively by specialized courts. Thus, of the 16 district courts of the federal state of Baden-Württemberg, only two can hear copyright and trademark disputes, and only one can handle patent claims ${ }^{21}$.

A characteristic feature of the protection of intellectual property rights in foreign countries is the fact that countries with high economic development, while protecting property rights, impose rather severe sanctions for infringement of intellectual property rights. For example, in analyzing the system of property rights protection in the United States, Bezpalko and N.P. Skrygun, emphasize that this state provides for criminal liability for copyright infringement and imprisonment of up to 10 years. The penalties provided for by Ukrainian law for copyright infringement are also severe enough: the maximum penalty for such actions in the criminal code is 6 years' imprisonment. But forensic provision of the solution of this problem, both in practical and theoretical aspect is quite difficult. This is due in the first place to the fact that protection of copyright and related rights has long been in the realm of

21 Боркамм И. Процессуальные действия по вопросам интеллектуальной собственности в рамках системы гражданского права: опыт Германии. URL: http://www.wipo.int/edocs/mdocs/enforcement/ru/wipo_ace_2/wipo_ace_2_3.pdf. 
civil law only ${ }^{22}$. At the scientific level, in particular in the scientific position of M.Ya. Melnikova stressed that the legislator should increase the level of penalties for violations in the specified area, depending on the level of public danger. The government must prove to the public that it will not condone copyright infringement in the field of information technologies and with their help. The facts of illegal distribution of works on the Internet, their public announcement in public places, establishments of trade, food, etc., have also become widespread ${ }^{23}$.

It should be noted that in most foreign countries there are specialized legal acts in which detailed regulation of protection of intellectual property rights is carried out. For example, in France the Code of Intellectual Property has been adopted. In characterizing this code, it states that the Intellectual Property Code consists of a legislative part, a regulatory part and a section on the application of rules in overseas territories. The legislative part contains general provisions on intellectual property rights. The regulatory part details the individual provisions of copyright, industrial property rights, legal means of individualization of participants in civil trafficking, goods and services. The Intellectual Property Code regulates the procedure for the implementation of international treaties ratified by France ${ }^{24}$.

Another area of copyright protection in the field of copyright is the widespread use of copyright and labor rights by employees who create copyright and intellectual property rights. The protection of the labor rights of creative workers is also reflected in the proper protection of intellectual property objects created by such workers, both independently and for the performance of the relevant official task. In particular, the protection of intellectual property rights is expressed in the criminal liability for violations of employees' rights to the results of their intellectual activity, which is enhanced in contrast to the Ukrainian legislation. For example, examining the peculiarities of criminal responsibility of the United States of America states that severe penalties are imposed under the laws of the United States of America for

22 Безпалько О.В. Проблематика захисту від «інтелектуального піратства» в світі і України. URL: http://dspace.nuft.edu.ua/jspui/bitstream/123456789/8957/1/piratstvo.

${ }^{23}$ Мельников М. Я. Піратство як злочин у галузі авторського права і суміжних прав: погляд на проблему // Право України. 2003. № 4. С.72-75.

24 Зінич Л.В. Особливості правового регулювання використання винаходів за законодавством Франції // Национальний юридический журнал: теория и практика. 2015. Декабрь. С. 136--138. 
counterfeiting and piracy. In particular, under US law, unauthorized reproduction of digital works (such as software products) and their pirated distribution (eg via the World Wide Web) is criminalized without the need to prove the offender's commercial advantage. The thresholds for bringing a criminal case for piracy under the laws of the United States of America are low and are based on the retail price of pirated goods ${ }^{25}$.

Therefore, after examining the most general aspects of intellectual property rights protection, we propose to agree with Yu. Yakimenko, who states that the state should take the following measures to ensure effective copyright protection:

- to establish a level of legal protection that complies with the rules of the main international treaties in the field of copyright;

- to condemn the illegal use of copyright objects;

- introduce rules that provide adequate compensation to copyright entities for the damage they cause;

- introduce into national law rules that provide for severe criminal penalties for illegal use of copyright objects;

- develop procedures to identify and prove cases of misuse of copyright objects;

- ensure the effective implementation of these sanctions and procedures.

\section{CONCLUSIONS}

It would also be appropriate to introduce a mediation practice for the settlement of disputes arising out of copyright infringement, such as that effectively applied in international practice, along with other alternative dispute resolution methods. This would help to unburden the state bodies that carry out copyright protection, reduce the terms of copyright protection cases, preserve in most cases partnerships between the parties to the conflict ${ }^{26}$. A similar opinion was expressed by T.V. regarding the definition of measures to improve civil liability for copyright infringement. The mine, which includes such measures: First, the issuance of regulations to regulate the field of copyright, especially with regard to issues related to the Internet; second, the state must provide effective

25 Захист прав інтелектуальної власності: норми міжнародного і національного законодавства та їх правозастосування: практичний посібник. - К. : К.І.С., 2007. 448 с.

${ }^{26}$ Якименко Ю.А. Способи захисту авторського права // Вісник Дніпропетровського ун-ту ім. Альфреда Нобеля. - Серія: Юридичні науки. 2015. № 1 (6). C. 37-41. 
mechanisms for bringing copyright offenders to justice, paying greater attention to measures to prevent offenses; third, an important role in the improvement of the civil legislation is played by bringing the normative legal acts in conformity with each other and international acts and standards, eliminating contradictions.

As a conclusion, in foreign highly developed countries considerable attention is paid to the protection of the labor rights of creative workers, which is due to the need to use the intellectual potential of the individual to improve production processes in enterprises. The peculiarity of protecting the rights of creative workers in foreign countries is to strengthen the protection of created objects of intellectual property, by expanding the types of offenses in the sphere of intellectual property and increased responsibility for their infringement, protection from downtime, etc.

\section{SUMMARY}

The main experience of foreign countries on the work of creative workers proposed in the Labor Code should clearly stipulate the peculiarities of regulating the work of creative workers, which, in our opinion, may consist of the following: 1) the emergence of employment relations with creative workers is an employment contract, a civil contract, a copyright contract, a contract agreement and more; 2) working conditions of the creative worker, which consist not only in the proper organizational and logistical support of the creative workers by the employer, but also protection against those factors that do not depend on the employer or employee (for example, protection of the creative worker from downtime; 3) normalization of labor. It is worth noting that the normalization of the work of the creative worker is quite difficult to understand the concept that follows from the specifics of creative activity; 4) remuneration.

Analyzing the problems of protection of intellectual property rights, the types of offenses in this area and the responsibility for their infringement are proposed to expand the list of offenses in the field of intellectual property. For example, in the case of France, it is proposed in the current legislation, namely the Code of Administrative Offenses to fix responsibility for such offenses as counterfeiting, misguided imitation, erroneous marking by amending the current Code of Administrative Offenses and fixing relevant articles offenses.

It is proposed at the legislative level to consolidate the ability of creative workers to use flexible working conditions and the ability of creative workers to work on the creation of an intellectual property right at home. 
The need for the establishment and existence of a specialized judiciary in Ukraine to handle cases arising from the use of intellectual property and intellectual property rights has been simplified. It is emphasized that the possibility of setting up specialized courts for the resolution of intellectual property disputes can be considered as a longterm perspective in the development of our country, which should be based on the experience of such courts in foreign countries and the analysis of the possibility of their introduction in the national court system. It is more appropriate to analyze the causes and conditions that contribute to the violation of the parties' rights in the intellectual property relationship, to legislatively enforce the terms of the intellectual property treaties and the agreements on the distribution of intellectual property rights, to define the conceptual foundations and ways of protecting intellectual property rights and their legislative consolidation.

\section{REFERENCES}

1. Охорона авторського права в Україні / http://osvita.ua/ vnz/reports/culture/11257/.

2. Гоцин Д.Р. Авторське право на студентські роботи // Молодий вчений. 2015. № 12 (27). Ч. 3. С. 79-83.

3. Право інтелектуальної власності: підручник для студентів вищих навч. закладів / [за ред. О.А. Підопригори, О.Д. Святоцького]. К.: Ін Юре, 2002. 624 с.

4. Баранов В.В. Світовий досвід побудови ефективної системи оплати праці на підприємстві // Наукові праці Кіровоградського націон. техн. Ун-ту. Економічні науки. 2011. Вип. 2. Ч. І. С. 139-145.

5. Мироненко Н.М. Захист прав на торговельні марки: українська практика та європейський досвід // Право України. 2011. № 3. С. 30-39.

6. Кодекс України про адміністративні правопорушення від 07.12.1984 № 8073-Х // Відомості Верховної Ради УРСР. 1984. № 51. Ст. 1122.

7. Право інтелектуальної власності: акад. курс: підруч. для студ. вищих навч. закладів / [О.П. Орлюк, Г.О. Андрощук, О.Б. БутнікСіверський та ін.]; за ред. О.П. Орлюк, О.Д. Святоцького. К.: Ін Юре, $2007.696 \mathrm{c}$.

8. Вахонєва Т.М. Захист трудових прав творчих працівників за законодавством держав світу // Наука і правоохорона. 2015. № 1. Ч. 2. С. 37-42. 
9. Кримінальний кодекс України: Закон України від 05.04.2001 № 2341-III // Відомості Верховної Ради України. 2001. № 25. CT. 131. 402.

10. Крупчан О.О. Міжнародно-правові механізми охорони i захисту авторських прав // Питання розвитку права інтелектуальної власності: збірник наукових праць. 2009. Вип. 8. С. 109-110.

11. Авторське право в міжнародно-правовому аспекті / Уклад. А.М. Євков Х.: 2010. 126 с.

12. Про авторське право і суміжні права: Закон Республіки Румунія від 14.03.1996 № 8 / http://www.wipo.int/wipolex/ru/text.jsp? file_id=129487.

13. Шибаєва Л.Л. Деякі особливості міжнародно-правової охорони права інтелектуальної власності // Форум права. 2016. № 3. С. 277-282.

14. Шадрина Т. С. Особенности трудового договора с творческими работниками // Учреждения культуры и искусства: бухгалтерский учет и налогообложение. 2012. № 11. С. 58-69.

15. Пресняков М. В. Особенности регулирования труда лиц до 18 лет // Трудовое право. 2010. № 6. С. 11-21.

16. Заярна Н.M. Зарубіжний досвід мотивації праці та доцільність його застосування в України // Науковий вісник НЛТУ України. 2011. Вип. 215. С. 368-372.

17. Богдан I.А. Умови праці як елемент трудо-правового забезпечення творчості // Юридична Україна. 2013. Вип. № 7 (127). С. 50-56.

18. Пархомчук С.О. Шляхи впровадження в судову систему України органів патентної юрисдикції // Часопис Київського університету права НАН України. 2012. № 2. С. 228-231.

19. Орлова В.В. Как работают патентные суды Германии и Великобритании // Патенты и лицензии. 2007. № 5. С. 57-66.

20. Порівняльне трудове право: навч. посіб. / [Б.С. Беззуб, Л.В. Голяк, О.М. Кісілевич та ін.]. К.: МАУП, 2005. С. 79-114.

21. Боркамм И. Процессуальные действия по вопросам интеллектуальной собственности в рамках системы гражданского права: опыт Германии // http://www.wipo.int/edocs/mdocs/enforcement/ ru/wipo_ace_2/wipo_ace_2_3.pdf

22. Безпалько О.В. Проблематика захисту від «інтелектуального піратства» в світі і України // Экономические науки. Серия: Маркетинг и менеджмент / http://dspace.nuft.edu.ua/jspui/bitstream/ 123456789/8957/1/piratstvo. 
23. Мельников М. Я. Піратство як злочин у галузі авторського права і суміжних прав: погляд на проблему // Право України. 2003. № 4. C. 72-75.

24. Зінич Л.В. Особливості правового регулювання використання винаходів за законодавством Франції // Национальний юридический журнал: теория и практика. 2015. Декабрь. С. 136-138.

25. Захист прав інтелектуальної власності: норми міжнародного і національного законодавства та їх правозастосування: практичний посібник - К. : К.I.C., 2007. 448 с.

26. Якименко Ю.А. Способи захисту авторського права // Вісник Дніпропетровського ун-ту ім. Альфреда Нобеля. - Серія: Юридичні науки. 2015. № 1 (6). С. 37-41.

Information about the author: Voloshina S. M.

$\mathrm{PhD}$ in Law, Associated Professor at the Department of Labour and Social Security Law National University "Odessa Law Academy" 2, Academychna str., Odessa, 65009, Ukraine 